\title{
Investment Need Plans Analysis Using ICOR Method in Kuningan Regency as Metropolitan Cirebon Raya
}

\author{
Neni Nurhayati \\ Universitas Kuningan \\ olive_1902@yahoo.com \\ Dadang Suhendar \\ Universitas Kuningan \\ dadangsuhendar@ymail.com
}

\begin{abstract}
This paper aimed at answering the goal of establishing Cirebon Raya Metropolitan as a center for economic development. Accelerated development is needed to increase economic growth in Kuningan Regency as one of the Greater Cirebon Metropolitan Area by increasing investment realization. Because one of the determinants of economic growth is investment, an analysis of the investment needs plan and data on investment sectors that are potential to be developed in Kuningan District are needed. Through this research, accurate data is obtained about the condition and development of investment in Kuningan Regency.To achieve this goal, an analytical description research method was conducted with data sources in the form of primary data and secondary data sourced from DPMTPSP, Bappeda, and BPS in Kuningan Regency related to Sectoral GRDP and investment data in both Kuningan and West Java Provinces. The data analysis technique uses the Incremental Capital Output Ratio (ICOR) method. This study lasted for 1 (one) year. The results of the study show that in welcoming the Greater Cirebon Metropolitan, the investment in the base sector in Kuningan Regency must be focused on the development of the Education Services, Transportation and Warehousing sector, and the agricultural and tourism products processing industries based on Agriculture, and natural resource potential.
\end{abstract}

Keywords: investment, ICOR, Kuningan Regency, Metropolitan Cirebon Raya JEL Classification: E22

INTRODUCTION

Ciayumajakuning region which consists of Indramayu Regency, Cirebon City, Cirebon Regency, Kuningan Regency, and Majalengka Regency, is one of the National Activity Centers that will become urban areas and serve to serve international, national, and several potential provinces to be developed. In addition to its abundant natural potential such as agriculture, plantations, fisheries, trade, services, oil and gas, the Ciayumajakuning region is also supported by a very strategic geographical position where access to Jakarta and Bandung and access 
to Semarang and Yogyakarta through this region. In addition, the topography of Ciayumajakuningpun is very supportive from the waters, coastal areas, beaches, plains, to mountainous areas where Cirebon Regency, Cirebon City and Indramayu Regency as coastal areas and Majalengka Regency and Kuningan Regency as a mountainous region. With these conditions it is not surprising that Ciayumajakuning was used as a location for infrastructure development, especially transportation infrastructure, both on land, sea and air, such as the construction of West Java International Airport in Kertajati, Majalengka Regency, and construction of Cipali Toll Road, Cisumdawu Toll Road and Cirebon Port.

In the regional context the Ciayumajakuning area was developed as a regional thematic area for the development of Greater Cirebon Metropolitan (MCR). This is in response to the West Java Regional Regulation No. 12 of 2014 concerning Management of Metropolitan Development and Development and Growth Centers in West Java. The principle of managing metropolitan development and growth centers in West Java is intended to:

1. Making the metropolitan area and center of growth the center of West Java's economic development

2. Making the metropolitan area and center of growth a driving force for improving people's welfare

3. Making the metropolitan area and growth center a starting point for building modernization in West Java

4. Making the metropolitan area and growth center a concrete step to create sustainable development.

In the West Javanese context contained in Perda No. 12 of 2014 there are three metropolitan areas that will be designed in the development of investments. Metropolitan Area is defined as a fast-growing region full of competition that has an important role in developing the economy of the region, is able to prosper the community, modernize, and sustainably develop, so that it needs to be well managed and developed as a driver of accelerated development in the region. One of the 3 (three) metropolitan areas intended by Perda No. 12 of 2014 was the Greater Cirebon Metropolitan. The MCR area consists of 1 city and 4 districts, namely Kuningan Regency, Cirebon City, Cirebon Regency, Indramayu Regency and Majalengka Regency, where Cirebon City is a metropolitan core city.

\section{LITERATURE REVIEW}

The Cirebon Raya Metropolitan Area is a new area that will grow. This can be shown based on the fact that the economic growth rate in the MCR region is still below the rate of economic growth in West Java during the period of 2012 - 2015. The low economic growth in the MCR region is inseparable from the conditions its territory. Cirebon Metropolitan 
Raya is an area that has not been used as an investment destination by investors both from within the country and abroad. Among regencies / cities in the MCR district, only Cirebon Regency and Cirebon City attract investors (Bappeda Provinsi Jawa Barat, 2016).

In an effort to implement Regional Regulation No. 12 of 2014, especially the foundation of the metropolitan area development - as the center of economic development, as a source of encouragement to improve community welfare, as a starting point for modernization of development in West Java, as well as concrete steps to create sustainable development in creating a metropolitan area become a center of growth, then one the way that can be done is to encourage economic growth in the metropolitan area.

Investment will greatly affect the level of economic growth that will be achieved by a region. Research conducted by Maulana (2013) and Suryono (2011) provide a conclusion that investment has a positive and significant effect on economic growth. The amount of investment in an area will affect the level of aggregate demand which will ultimately affect the level of output produced. Kuningan Regency as one of the regencies located in the Cirebon Metropolitan Area Raya still has a low investment amount compared to other municipal districts in the MCR region (West Java Province BKPPMD). The unavailability of data related to investment plan information and investment sector data that has the potential to be developed that can be used as study material in making investment decisions makes investors' interest in investing in Kuningan Regency to be low. The low interest in investing is evident from the low investment realization embedded in Kuningan Regency. This makes Kuningan District less investment competitiveness compared to other districts / cities in the Ciayumajakuning region which will be developed as a regional thematic area of the development of Cirebon Raya Metropolitan as mandated by Perda No. 12 of 2014.

The low investment competitiveness in Kuningan Regency makes Kuningan Regency a low level of economic growth. To answer the goal of establishing Cirebon Raya Metropolitan as a center for economic development, accelerated development is needed to increase economic growth in Kuningan Regency as one of the Greater Cirebon Metropolitan Area by increasing investment realization. Because one of the determinants of economic growth is investment, an analysis of the investment needs plan and data on investment sectors that are potential to be developed in Kuningan District are needed. In order for the target to be determined realistically an indicator related to investment is needed. The indicator needed is Incremental Capital Output Ratio (ICOR) or the ratio between additional output and additional capital. If an area has an 
ICOR number, then the region will not find it difficult to determine the amount of investment needed to pursue the desired economic growth target. The smaller the ICOR value the greater the productivity and efficiency of the investment invested.Investment will strengthen economic growth by bringing more input into the production process. Improving the investment climate is an important task for every government, especially districts / cities that have low investment competitiveness such as Kuningan Regency.

Based on this background, the authors made a study of the analysis of the investment needs plan using the Incremental Capital Output Ratio (ICOR) method in Kuningan Regency in preparing themselves to become the Greater Cirebon Metropolitan Area. This research is very important because through this research accurate data about the investment needs plan in Kuningan Regency can be obtained and what investment sector data has the potential to be developed in Kuningan Regency in preparing to become the Greater Cirebon Metropolitan Area.

\section{METHOD, DATA AND ANALYSIS -Research method}

The research method used is descriptive analytical method that is a method that aims to describe or provide an overview of an object of research examined through collected samples or data and make generally accepted conclusions (Sugiyono, 2009).
-Data

The study was conducted in Kuningan Regency in 1 (one) year. The population in this study is Sectoral GRDP calculated based on the constant price of 2000 as well as investment data in both Kuningan District and West Java Province. In this study no sample is needed because the overall object of research can be reached by the researcher. The population studied is the GRDP of all sectors calculated based on constant prices and investment data in both the Kuningan District and West Java Province for the 2014-2016 periods. Data collection techniques are by means of library research, field research, observation, and interviews.

\section{-Analysis}

The analysis technique used in this study is divided into several stages. The initial stage in analyzing the investment needs plan requires an analysis of the calculation of economic aspects, namely the analysis of the rate of economic growth, the results of this calculation are used as the basis for calculating the Incremental Capital Output Ratio (ICOR) of Kuningan district. After obtaining the ICOR value, the next step is to determine the amount of long-term investment needs in Kuningan district. Whereas to find out the potential investment sector is used the Location Quotient (LQ) analysis by comparing the role of a sector in Kuningan Regency to the role of a sector nationally at the provincial level.

1. Analysis of Economic Aspect Calculations (analysis of Economic 
Growth Rate)

$$
L P E_{(n, i)}=\frac{P D R B_{(n, k, i)}-P D R B_{(n-l, k, i)}}{P D R B_{(n-l, k, i)}} X 100 \%
$$

2. Analysis of Calculation of Incremental Capital Output Ratio (ICOR)

Incremental Capital Output Ratio (ICOR) is a quantity that shows the amount of additional new capital (investment) needed to increase / increase one unit of output. ICOR is also used to measure how much investment is needed to increase economic growth.

Formula:

$$
\mathrm{ICOR}=\mathrm{K} / \Delta \mathrm{Y}
$$

In its development, the data used to calculate ICOR is no longer just the addition of new capital goods or changes in capital stock alone but investment (I) invested both by the public, private and government entrepreneurs, so that the ICOR formula can be modified as follows:

$$
\mathrm{ICOR}=\mathrm{I} / \Delta \mathrm{Y}
$$

Notes:

$\mathrm{K}=$ Change in Capital Value

I= Amount of Investment

$\Delta \mathrm{Y}=$ Economic Growth

3. Analysis of Long Term Investment Needs Plans

Long-term investment needs are investment plans that will be carried out in improving the regional economy. The aim of the analysis of the plan for long-term investment needs is to find out how much investment value must be obtained to increase the economy during the study period, which is until the end of 2030 by using forecasting.

The formula for calculating the Investment Need Plan is:

$\mathrm{I}=\mathrm{k} * \mathrm{~g} * \mathrm{Y}$

Notes:

I = Amount of Investment

$\mathrm{k}=$ ICOR number

$\mathrm{g}=$ Economic Growth Rate

$Y=P D R B$

4. Anal sis of the Investment Leading Sector Location Quotient (LQ)

Location Quotient (LQ) is a comparison of the magnitude of the role of a sector in a certain area of the role of a sector nationally or in a district on the role of a regional or provincial level sector. Location Quotient (LQ) analysis tool is intended to identify and formulate the composition and shift of the basic sectors of a region by using GRDP data as an indicator of regional growth (Adoisasmita, 2005: 29).

To find out the basic sector and non-base economy in an area can refer to the formulation of Bendavid (1991) with the following equation:

$L Q=\frac{\mathrm{Si} / \mathrm{S}}{\mathrm{Ni} / \mathrm{N}}$

Notes:

LQ = Location Quotien

$\mathrm{Si}=$ production value in an area 
sector in Kuningan Regency in particular year $\mathrm{Ni}=$ total production value in Kuningan Regency in a given year $\mathrm{S}=$ value of sector production in West Java in a given year $\mathrm{N}=$ total production value in West Java in a given year.

The criteria for measuring LQ values are generated as follows: - If LQ> 1 means the level of specialization in sector $I$ in Kuningan district is greater than the same sector in West Java. So it can be concluded that this sector is a base sector and has the potential to be developed as a driver of the economy in the Kuningan district

- - If LQ $<1$ means the level of specialization in sector $I$ in Kuningan Regency is smaller than the same sector in West Java. So that it can be concluded that this sector is a non-base sector and has no potential to be developed as a driver of the economy in the Kuningan district.

\section{RESULT AND DISCUSSION}

\section{- Results}

Table 1. Economic Growth in Kuningan Regency

2011- 2016 (Percentage)

\begin{tabular}{cc}
\hline Year & PDRB \\
\hline 2011 & 5,62 \\
2012 & 5,71 \\
2013 & 6,25 \\
2014 & 6,32 \\
2015 & 6,38 \\
2016 & 6,09 \\
Average & 06.06 \\
\hline
\end{tabular}


Source: Investment Services and One Stop Services in Kuningan Regency -

West Java (2017)

The group that experienced positive growth consisted of 8 economic categories including:

Table 2. Economic Category with Positive Growth in Kuningan District in

\begin{tabular}{clc}
\multicolumn{2}{c}{2016} & \\
\hline No & \multicolumn{1}{c}{ Category } & Percentage \\
\hline 1 & Agriculture, Forestry & 3,44 \\
& and Fisheries \\
2 & Processing industry & 0,79 \\
3 & $\begin{array}{l}\text { Procurement of } \\
\text { Electricity and Gas }\end{array}$ & 2,88 \\
4 & Large and Retail & 1 \\
& Trade; motorcycle & \\
& repair & \\
5 & Financial and Insurance & 0,72 \\
& Services & \\
6 & Real Estate & 1,7 \\
7 & Company Services & 0,84 \\
8 & Government, Defense & 0,78 \\
& and Mandatory & \\
& Administration & \\
\hline
\end{tabular}

Source: Investment Services and One Stop Services in Kuningan Regency - West Java (2017)

While the economic category that experienced a slowdown in growth included:

Table 3. Economic category with slowing growth in Kuningan District in 2016

\begin{tabular}{clc}
\hline No & \multicolumn{1}{c}{ Category } & Percentage \\
\hline 1 & Mining and excavation & $-0,87$ \\
2 & Water Supply, Waste, & $-0,3$ \\
& Waste and Repeat & \\
& Management & \\
3 & Construction & $-4,72$ \\
4 & Transportation and & $-2,1$ \\
& Warehousing & \\
5 & $\begin{array}{l}\text { Provision of } \\
\text { Accommodation and }\end{array}$ \\
& Eating Drinks
\end{tabular}




$\begin{array}{lll}6 & \text { Information and } & -4,31 \\ & \text { Communication } & \\ 7 & \text { Education Services } & -4,44 \\ 8 & \text { Health Services and } & -4,91 \\ & \text { Social Activities } & \\ 9 & \text { Other services } & -3,67\end{array}$

Source: Investment Services and One Stop Services in Kuningan Regency - West Java (2017)

\section{Kuningan Regency Investment}

Realization of PMDN / PMA Kuningan

Regency from 2011 to 2016 reached

Rp. $2.5 \mathrm{~T}$ with an investment target

of Rp. $1.7 \mathrm{~T}$ so that the target achievement ratio reaches $149.82 \%$.
The following is presented in the table of recapitulation of realization of PMA / PMDN investments in 2011 to 2016 in Kuningan Regency.

Table 4. Recapitulation of Realization of PMA / PMDN Investment in 2011 up to 2016 in Kuningan Regency

\begin{tabular}{ccccccc}
\hline No & Year & $\begin{array}{c}\text { Number of } \\
\text { Companies }\end{array}$ & $\begin{array}{c}\text { Number } \\
\text { of } \\
\text { Employee }\end{array}$ & $\begin{array}{c}\text { Target of } \\
\text { Investment } \\
\text { (Rp) }\end{array}$ & $\begin{array}{c}\text { Realisation of } \\
\text { Investment } \\
\text { (Rp) }\end{array}$ & $\begin{array}{c}\text { Percentage } \\
\text { (Rp) }\end{array}$ \\
\hline $\mathbf{1}$ & 2011 & 790 & 1588 & 180.000 .000 .000 & 283.992 .729 .258 & 157.77 \\
$\mathbf{2}$ & 2012 & 664 & 1287 & 226.500 .000 .000 & 488.782 .757 .717 & 215.80 \\
$\mathbf{3}$ & 2013 & 695 & 2046 & 250.000 .000 .000 & 359.967 .762 .200 & 143.99 \\
$\mathbf{4}$ & 2014 & 760 & 4091 & 302.500 .000 .000 & 448.839 .079 .180 & 148.38 .00 \\
$\mathbf{5}$ & 2015 & 570 & 2219 & 347.500 .000 .000 & 397.813 .949 .380 & 114.48 .00 \\
$\mathbf{6}$ & 2016 & 1003 & 4131 & 399.500 .000 .000 & 576.411 .621 .949 & 144.28 .00 \\
\hline
\end{tabular}

Based on the table above, it can be seen that the achievement of the largest investment shield during the period of 2011 to December 2016 occurred in 2016 with the realization of an investment of Rp. 576,477,621,949. However, this figure is still minimal for the size of Kuningan Regency which incidentally has great potential to be developed. Kuningan Regency has natural resources (SDA) which boast as an area in the area east of the foot of Mount Ciremai with abundant potential to be developed further. These potentials such as water, agriculture, plantations, fisheries, industry and trade, even tourism such as historical tourism, educational tourism, natural, rural, forest and water tourism are very fascinating and have a great attraction for nature lovers. 
Table 5. Analysis of Calculation of Incremental Capital Output Ratio (ICOR)

\begin{tabular}{|c|c|c|c|c|c|c|}
\hline & 2011 & 2012 & 2013 & 2014 & 2015 & 2016 \\
\hline Invest & 283.992 .7 & 488.782 .7 & 359.967 .7 & 448.839 .0 & 397.813 .9 & 576.411 .6 \\
\hline $\begin{array}{l}\text { ment } \\
(\mathrm{Rp})\end{array}$ & 29.258 & 57.717 & 62.200 & 79.180 & 49.380 & 21.949 \\
\hline PDRB & 10.371 .17 & 10.962 .96 & 11.648 .53 & 12.385 .38 & 13.175 .67 & 13.977. \\
\hline $\begin{array}{l}\text { ADHK } \\
2010 \\
\text { (Rp } \\
\text { millio } \\
\text { n) }\end{array}$ & 5,26 & 4,00 & 9,43 & 2,11 & 1,72 & 774,24 \\
\hline$\Delta$ & & 204.790 .0 & - & 88.871 .31 & - & 178.597 .6 \\
\hline $\begin{array}{l}\text { Invest } \\
\text { ment } \\
(\mathrm{Rp})\end{array}$ & & 28.459 & $\begin{array}{l}128.814 .9 \\
95.517\end{array}$ & 6.980 & $\begin{array}{l}51.025 .12 \\
9.800\end{array}$ & 72.569 \\
\hline$\Delta$ & & $591.788,7$ & $685.575,4$ & $736.842,6$ & $790.289,6$ & $802.102,5$ \\
\hline $\begin{array}{l}\text { PDRB } \\
\text { ADHK } \\
2010 \\
\text { (Rp } \\
\text { millio } \\
\text { n) }\end{array}$ & & 4 & 3 & 8 & 1 & 2 \\
\hline ICOR & & 0,82 & 0,52 & 0,61 & 0,5 & 0,72 \\
\hline \multicolumn{7}{|c|}{ Average of ICOR 0.63} \\
\hline
\end{tabular}

Based on the table above, it can be seen that the highest ICOR during the observation period of 2012 to 2016 occurred in 2012 with an ICOR value of 0.82 . However, the lowest

ICOR occurred in 2015. Thus the ICOR average in Kuningan Regency during the observation period was 2011 to 2016 amounting to 0.63

\section{Analysis of Long-Term Investment Needs Plans}

Table 6. Plan for Long Term Investment Needs Kuningan Regency until 2030

\begin{tabular}{|c|c|c|c|c|c|c|c|}
\hline Year & 2017 & 2018 & 2019 & 2020 & 2021 & 2022 & 2023 \\
\hline $\begin{array}{l}\text { Economic growth } \\
\text { (\%) }\end{array}$ & 6,5 & 6,5 & 6,5 & 6,5 & 6,5 & 6,5 & 6,5 \\
\hline $\begin{array}{l}\text { PDRB ADHK } \\
\text { (Billion Rupiah } \\
\text { Rp) }\end{array}$ & $\begin{array}{c}14866,6 \\
2\end{array}$ & 15832,95 & $\begin{array}{r}16862,09 \\
2\end{array}$ & $\begin{array}{r}17958,12 \\
8\end{array}$ & 19125,406 & 20368,558 & 21692,514 \\
\hline ICOR & 0,63 & 0,63 & 0,63 & 0,63 & 0,63 & 0,63 & 0,63 \\
\hline Investment needs & 608,788 & 648,3593 & 690,5026 & 735,3853 & 783,18539 & 834,09244 & 888,30845 \\
\hline
\end{tabular}


Neni Nurhayati, Dadang Suhendar

Investment Need Plans Analysis Using ICOR Method in Kuningan Regency as Metropolitan Cirebon Raya

(Billion Rupiah)

09

1

7

4

\begin{tabular}{|c|c|c|c|c|c|c|c|}
\hline Year & 2024 & 2025 & 2026 & 2027 & 2028 & 2029 & 2030 \\
\hline $\begin{array}{l}\text { Economic growth } \\
\text { (\%) }\end{array}$ & 6,5 & 6,5 & 6,5 & 6,5 & 6,5 & 6,5 & 6,5 \\
\hline $\begin{array}{l}\text { PDRB ADHK } \\
\text { (Billion Rupiah } \\
\text { Rp) }\end{array}$ & $\begin{array}{r}23102,5 \\
27\end{array}$ & $\begin{array}{r}24604,19 \\
2\end{array}$ & $\begin{array}{r}26203,46 \\
4\end{array}$ & $\begin{array}{r}27906,68 \\
9\end{array}$ & 29720,624 & 31652,465 & 33709,875 \\
\hline ICOR & 0,63 & 0,63 & 0,63 & 0,63 & 0,63 & 0,63 & 0,63 \\
\hline $\begin{array}{l}\text { Investment needs } \\
\text { (Billion Rupiah) }\end{array}$ & $\begin{array}{r}946,048 \\
5\end{array}$ & $\begin{array}{r}1007,541 \\
7\end{array}$ & $\begin{array}{r}1073,031 \\
9\end{array}$ & $\begin{array}{r}1142,778 \\
9\end{array}$ & 1217,0596 & 1296,1684 & 1380,4194 \\
\hline
\end{tabular}

Source: Analyzed data

As the effort of Kuningan Regency in spurring development, the table above is useful for the target of economic growth rate with a certain amount. The above table illustrates if in 2019 expected economic growth is $6.5 \%$ (due to the average economic growth of $6.06 \%$ ) and the constant ICOR value of 0.63 per year, the amount of investment needs to be made is Rp. $690 \mathrm{M}$. Likewise for the next year period if it is assumed to be the same then the amount of investment needs can be projected up to 2030 .

Analysis of the Investment Leading Sector Location Quotient (LQ)

Table 7. Location Quotient (LQ) of Kuningan Regency

2011 - 2016.

\begin{tabular}{|c|c|c|c|c|c|c|c|c|c|}
\hline \multirow{3}{*}{ Economic category } & \multicolumn{7}{|c|}{ Location Quotient (LQ) } & \multirow{3}{*}{ Average } & \multirow{3}{*}{ Notes } \\
\hline & \multicolumn{7}{|c|}{$P D R B$} & & \\
\hline & 2010 & 2011 & 2012 & 2013 & 2014 & 2015 & 2016 & & \\
\hline $\begin{array}{l}\text { Agriculture, Forestry } \\
\text { and Fisheries }\end{array}$ & 0,142 & 0,146 & 0,147 & 0,144 & 0,143 & 0,143 & 0,140 & 0,144 & Basis \\
\hline Mining and excavation & 0,042 & 0,045 & 0,050 & 0,053 & 0,053 & 0,053 & 0,053 & 0,050 & Non Basis \\
\hline Processing industry & 0,004 & 0,004 & 0,003 & 0,004 & 0,004 & 0,004 & 0,004 & 0,004 & Non Basis \\
\hline $\begin{array}{l}\text { Procurement of } \\
\text { Electricity and Gas }\end{array}$ & 0,012 & 0,013 & 0,013 & 0,013 & 0,013 & 0,013 & 0,014 & 0,013 & Non Basis \\
\hline $\begin{array}{l}\text { Water Supply, Waste } \\
\text { Management, Waste } \\
\text { and recycling }\end{array}$ & 0,053 & 0,053 & 0,054 & 0,054 & 0,053 & 0,051 & 0,051 & 0,053 & Basis \\
\hline Construction & 0,053 & 0,051 & 0,048 & 0,049 & 0,049 & 0,049 & 0,047 & 0,049 & Basis \\
\hline $\begin{array}{l}\text { Large and Retail } \\
\text { Trade, Car and } \\
\text { Motorcvcle Repair }\end{array}$ & 0,052 & 0,052 & 0,049 & 0,049 & 0,049 & 0,048 & 0,047 & 0,049 & Basis \\
\hline $\begin{array}{l}\text { Transportation and } \\
\text { Warehousing }\end{array}$ & 0,137 & 0,131 & 0,127 & 0,130 & 0,128 & 0,152 & 0,149 & 0,128 & Basis \\
\hline $\begin{array}{l}\text { Provision of } \\
\text { Accommodation and } \\
\text { Eating Drinks }\end{array}$ & 0,051 & 0,051 & 0,051 & 0,051 & 0,050 & 0,050 & 0,049 & 0,051 & Non Basis \\
\hline
\end{tabular}




\begin{tabular}{|c|c|c|c|c|c|c|c|c|}
\hline $\begin{array}{l}\text { Information and } \\
\text { Communication }\end{array}$ & 0,083 & 0,072 & 0,072 & 0,071 & 0,069 & 0,067 & 0,065 & 0,072 \\
\hline $\begin{array}{l}\text { Financial and } \\
\text { Insurance Services }\end{array}$ & 0,096 & 0,097 & 0,097 & 0,094 & 0,092 & 0,092 & 0,088 & 0,094 \\
\hline Real estate & 0,129 & 0,131 & 0,133 & 0,133 & 0,131 & 0,128 & 0,128 & 0,131 \\
\hline Company Services & 0,046 & 0,045 & 0,046 & 0,045 & 0,044 & 0,043 & 0,043 & 0,044 \\
\hline $\begin{array}{l}\text { Government } \\
\text { administration, } \\
\text { Defense, and } \\
\text { Mandatory Social } \\
\text { Security }\end{array}$ & 0,099 & 0,105 & 0,104 & 0,106 & 0,106 & 0,100 & 0,099 & 0,103 \\
\hline Education Services & 0,149 & 0,149 & 0,126 & 0,147 & 0,154 & 0,160 & 0,165 & 0,142 \\
\hline $\begin{array}{l}\text { Health Services and } \\
\text { Social Activities }\end{array}$ & 0,098 & 0,099 & 0,099 & 0,103 & 0,100 & 0,098 & 0,097 & 0,099 \\
\hline Other services & 0,090 & 0,005 & 0,092 & 0,092 & 0,093 & 0,094 & 0,094 & 0,076 \\
\hline
\end{tabular}

Source: BPS of Kuningan Regency (analyzed data)

Based on the table above, it can be concluded as follows:

1. Kuningan Regency has economic potential which falls into the category of superior economy when compared to the conditions in the West Java Province as a whole.

The 13 categories are

1. Agriculture, Forestry and Fisheries

2. Water Procurement, Waste Management, Waste and recycling

3. Construction

4. Large and Retail Trade, Car and Motorcycle Repair

5. Transportation and Warehousing

6. Information and Communication

7. Financial and insurance services

8. Real estate

9. Company Services

$10 . \quad$ Government administration, Defense and Mandatory Social Security

11. Educational Services

12. Health Services and Social Activities

13. Other Services

2. Kuningan Regency has economic potential which is included in the non-superior economic category when compared to the conditions in the West Java Province as a whole.

The 4 categories include:

1. Mining and quarrying

2. Processing Industry

3. Procurement of Electricity and Gas

4. Provision of Accommodation and Eating Drinks

Nevertheless, this nonsuperior sector category that is considered to be less potential cannot be ignored. Because it is possible to have assistance from a superior sector that can help the growth and development of 
the non-superior sector become a new leading sector.

3. The highest order of LQ from several sector bases in Kuningan Regency is:

1. Educational Services

2. Transportation and Warehousing

3. Agriculture, Forestry and Fisheries

\section{-Discussions}

The investment strategy in the base sector in Kuningan Regency is focused on development in the Education, Transportation and Warehousing, and Agriculture, Forestry and Fisheries sectors. The education sector is the capital to improve the quality of human resources in Kuningan Regency. The Transportation and Warehousing Sector is intended to facilitate travel traffic that supports tourism access. While the Agriculture, Forestry and Fisheries sector is focused on increasing agricultural productivity, agricultural products processing industries, and agriculture-based tourism and natural resource potential.

Investment in Kuningan

Regency is focused on investments that are able to support Kuningan Regency as the main buffer zone of the Greater Cirebon Metropolitan. The linkages between Education Services, Transportation and Warehousing, and Agriculture, Forestry, and Fisheries are very much needed in Kuningan Regency. The existence of these 3 leading sectors allows Kuningan Regency to be able to increase economic growth in the face of Greater Cirebon Metropolitan.

The strategies that can be carried out by Kuningan Regency include increasing investment attractiveness focused on the Education Services, Transportation and Warehousing sector and agricultural and tourism products processing industries based on Agriculture, and the potential of natural resources in order to increase regional economic growth. To support the improvement of the investment climate in Kuningan Regency, it is also necessary to collaborate with the government and the private sector in the provision of investment, especially leading sector investments that have high potential to be developed. In addition, there is also a need to improve various aspects of both institutions and adequate regulations and support the creation of a good investment climate in Kuningan Regency by considering a SWOT analysis so that appropriate strategies can be drawn up to increase interest in investing in Kuningan Regency.

\section{CONCLUSION}

In commemorating Cirebon Raya as Metropolitan area, the investment in the base sector in Kuningan Regency is focused on the development of the Education, Transportation and Warehousing sector and agricultural and tourism products processing industries based on Agriculture, and the potential of natural resources. Investment in Kuningan Regency is focused on investments that are able to 
support Kuningan Regency as the main buffer zone of the Greater Cirebon Metropolitan. The linkages between Education Services, Transportation and Warehousing, and Agriculture, Forestry, and Fisheries are very much needed in Kuningan Regency. The existence of these 3 leading sectors allows Kuningan Regency to be able to increase economic growth in the face of Greater Cirebon Metropolitan.

\section{IMPLICATION/ LIMITATION AND SUGGESTION}

The limitation in this study is that the observation period is not long, besides that the research location is only limited to Kuningan Regency while the MCR area covers 4 districts and 1 city.

Based on the results of the study, the strategies that can be carried out by Kuningan Regency in commemorating Cirebon Raya as Metropolitan area include increasing investment attractiveness focused on the Education, Transportation and Warehousing sector, and agricultural and tourism products processing industries based on Agriculture, and natural resource potential in order to improve regional economic growth. To support the improvement of the investment climate in Kuningan Regency, it is also necessary to collaborate with the government and the private sector in the provision of investment, especially leading sector investments that have high potential to be developed. In addition, there is also a need to improve various aspects of both institutions and adequate regulations and support the creation of a good investment climate in Kuningan Regency by considering a SWOT analysis so that appropriate strategies can be drawn up to increase interest in investing in Kuningan Regency.

\section{REFERENCES}

Rencana kebutuhan Investasi Metropolitan BODEBEKKARPUR tahun 2016. Retrieved from http:/ /bappeda.jabarpro v.go.id/wpcontent/uploads/old_do c/Laporan_Akhir_Rencan a_Kebutuhan_Investasi_ Metropolitan_BODEBEKK ARPUR_2016.pdf.

Badan Pusat Statistik Kabupaten Kuningan. (2011, 2012, 2013, 2014, 2015, 2016). Kuningan dalam Angka 2011. Kuningan: Badan Pusat Statistik Kabupaten Kuningan.

BPS Provinsi Jawa Barat. (2016). PDRB menurut lapangan usaha Provinsi Jawa Barat. Bandung: Badan Pusat Statistik Provinsi Jawa Barat

Maulana. (2013). Analisis Pengaruh Investasi, Tenaga Kerja, dan Tingkat Pendidikan Terhadap Pertumbuhan Ekonomi Jawa Barat.

Perda No. 12 Tahun 2014 tentang Pengelolaan 


Pembangunan dan
Pengembangan
Metropolitan dan Pusat
Pertumbuhan di Jawa
Barat. Retrieved from
http://www.jdih.setjen.
kemendagri.go.id/files/P
_JABAR_12_2014.pdf.

Sirojuzilam. (2011). Problematika Wilayah Kota dan daerah, Medan: USU Press.

$\begin{array}{lr}\text { Suryono. (2011). } & \text { Analisis } \\ \text { pengaruh PAD, Tingkat } \\ \text { Investasi, dan Tenaga } \\ \text { Kerja Terhadap PDRB } \\ \text { Jawa } & \text { Tengah } \\ \text { (Undergraduate Thesis, } \\ \text { Diponegoro University, } \\ \text { Semarang, Indonesia). } \\ \text { Retrieved r from } \\ \text { http://eprints.undip.ac.i } \\ \text { d/26434/1/Skripsi_Kesel } \\ \text { uruhan_l.pdf }\end{array}$

